\title{
Cooperation across cultures: An examination of the concept in 16 countries
}

\author{
Karen Moustafa Leonard ${ }^{\mathrm{a}, *}$, Christopher Cosans $^{\mathrm{a}}$, Fatma Pakdil ${ }^{\mathrm{b}}$, Country Collaborator ${ }^{1}$ \\ a Indiana University-Purdue University Fort Wayne, United States \\ b Baskent University, Ankara, Turkey
}

\section{A R T I C L E I N F O}

\section{Article history:}

Received 14 July 2010

Received in revised form 13 January 2011

Accepted 15 March 2011

\section{Keywords:}

Cooperation

Culture

Management

Individualism

Collectivism

Power distance

\begin{abstract}
A B S T R A C T
Businesses are coordinated organizations, and cooperation among employees reduces overall organizational costs. Understanding how important cooperation is among different cultures is important, as business becomes increasingly global. However, cross-cultural literature on cooperation deals with firm alliances, joint ventures, and other firm interrelationships, but not on societal differences in cooperation. Is cooperation similar across cultures? Using proxies, this study sought to operationalize cooperation and examine its underpinnings in countries, using the cultural dimensions of individualism and power distance. Although the initial hypotheses stated that cooperation would look different across these dimensions, the international set of 6452 respondents showed that the overwhelming majority had a similar view of cooperation. The study adds to our understanding of cooperation in different societies and contexts, and suggests that there may be a universal view of cooperation across cultures.
\end{abstract}

(C) 2011 Elsevier Ltd. All rights reserved.

\section{Introduction}

\subsection{Cross-cultural of cooperation at the individual level}

Businesses have been defined as coordinated organizations, dependent upon cooperation of employees (Barnard, 1938). The need to work toward "promotively interdependent goals" (Deutsch, 1949:132) requires that firms understand how to capture and build cooperation. Roberts (2006) and Seligman and Csikszentmihalyi (2000) identified cooperation as a probative workplace trait, essential for workplace survival (Avolio \& Luthans, 2006; Sutcliffe \& Vogus, 2003). Organizations with highly interdependent tasks foster the need for cooperation as they try to move from local to global functioning, often using such things as virtual teams (Allred, Snow, \& Miles, 1996).

Kerr (1975) argued that organizations cannot depend on chance cooperation. Borman and Motowidlo (1993) stated that the reduction in communication barriers during cooperation reduces overall organizational costs. However, managers must convince employees that cooperation is important by emphasizing the need to achieve a common goal for a common benefit (Barnard, 1938). Although this literature is not recent, it is worth reviewing for its current application in modern global organizations. Since the initial work in this area, few have examined cooperation across cultures in terms of individual preferences or reactions. Much has been limited to firm networks, joint ventures, or strategic alliances (cf., Contractor \&

\footnotetext{
* Corresponding author. Tel.: +12604816491.

E-mail address: moustafk@ipfw.edu (K.M. Leonard).

1 See Appendix A.
} 
Lorange, 2002; Holm, Eriksson, \& Johnson, 1996; Park \& Russo, 1996; Sattler, Schrader, \& Luthje, 2003; Wilkinson \& Young, 2001).

And as many have discussed, it is crucial to understand those functioning in different societies and contexts as the workforce becomes global (cf., Bhagat, Kedia, Harveston, \& Triandis, 2002; Motowidlo \& Schmit, 1999). Cultural dimensions are so much more than individual determinants of behavior; they also influence how people interact within organizational settings (Hofstede, 2001; Triandis, 2000). When cultures and firms intertwine, interesting dynamics are likely to result. The research question examined in this study is whether cooperation can be operationalized through proxies (i.e., concrete measures representing cooperation) in the same manner in cultures with various cultural dimension ratings (Hofstede, 2001), specifically in terms of individualism and power distance. The direct outcome of this proxy would indicate whether there is truly a difference in the value of cooperation across cultures with various ratings of individualism and power distance.

\subsection{Overview of cooperation research}

Cooperation is essential, because organizational goals are only achieved when members cooperate to reach them. The form of cooperation may be deliberate or accidental, kind or contentious, but cooperation exists or the organization cannot (Barnard, 1938). Roberts (2006) and Seligman and Csikszentmihalyi (2000) identified cooperation as a positive workplace trait, especially important as exceptional performance becomes increasingly necessary for workplace survival (Avolio \& Luthans, 2006; Sutcliffe \& Vogus, 2003). Therefore, organizations with highly interdependent tasks foster the need for cooperation.

Cooperation often requires incentives, as self-interested individuals are more likely to cooperate when rewards result (Kerr, 1975; Smith, 1776/1991). However, many researchers view cooperation as a socialization of values that induces compliance with social norms (cf., Durkheim, 1938). If cooperation is a social norm in a society, then members will be socialized into cooperative behaviors. Deutsch (1949) found that, in general terms, people readily cooperation if (a) they see that their goals are interrelated and (b) cooperation will help them achieve them.

Deutsch (1949), Durkheim (1938), and Smith (1776/1991) saw cooperation in a broad sense, across different organizations and societal structures in the West. However, from a social exchange perspective (Blau, 1964; Homans, 1974), based on research in Western societies, cooperation is based on reciprocity (Fehr \& Gintis, 2007; Gouldner, 1960). In other words, cooperation by one person creates an expectation of cooperation by the other (Koster \& Sanders, 2006).

Individuals also make sacrifices to punish those who violate norms as to the appropriateness of the exchanges (Fehr \& Gintis, 2007). Studies in the West show that, when punishment opportunities are given, cooperation rates increase, sometimes to 100 percent (Anderson \& Putterman, 2006; Ostrom, Walker, \& Gardner, 1992; Yamagishi, 1986). If there are costs to self-interested behaviors, then individuals are more likely to reciprocate (Anderson \& Putterman, 2006; Carpenter, 2007).

Cooperation has been found to be an important component in organizational behavior research in organizations. Individual cooperation in work activities has been shown to increase organizational loyalty (Hage, 1980; Hirschman, 1970) and improve organizational commitment (Mowday, Steers, \& Porter, 1982). Research also defines cooperation as a main part of contextual performance or organizational citizenship behaviors (Borman \& Motowidlo, 1993; LePine \& Van Dyne, 2001; Organ, 1997; Van Dyne et al., 1995) and prosocial organizational behavior (Koster \& Sanders, 2006). The most frequently studied form of cooperative behavior is contextual performance or organizational citizenship behaviors (Koster \& Sanders, 2006; Van Scotter, Motowidlo, \& Cross, 2000), with the majority of work done in Western societies. Contextual performance has, at its root, the idea that individuals will help each other and work together to achieve organizational goals.

In the West, excellent performers, those whose work regularly exceeds the average, use cooperation as a useful strategy more often than do moderate performers (Sonnentag, 2000). Sonnentag also found that peers use cooperation as a measure of competency when describing excellent performers (Ericsson \& Charness, 1994). This is important in organizations relying more on teamwork and other cooperative arrangements (Stevens \& Campion, 1994; West, Borrill, \& Unsworth, 1998). Therefore, organizations with highly interdependent tasks have attempted to foster cooperation as they move from individualized work to team work (Allred et al., 1996) and from local to global functioning.

\subsection{Cultural dimensions relevant to the current study}

Individuals living in various areas of the world have different orientations to their environments, resulting in different approaches to dealing with local geographical, political, and economic situations (Hofstede, 2001; Triandis, 1996). Culture consists of the norms, values, beliefs, and attitudes of a group of people, and often the definition includes traditional practices. It is thought to be a reaction to environmental situations (cf., Hofstede, 2001; Kluckhohn, 1954). Although the multitude of definitions and dimensions of culture are breathtaking, most indicate that elements are shared within each culture (cf., Hofstede, 2001; Kluckhohn, 1954; Skinner, 1981; Shweder \& LeVine, 1984), including ways of "perceiving, believing, evaluating, communicating, and acting" (Triandis, 1996: 408). Culture often appears to be virtually seamless - not requiring much conscious thought to incorporate the norms, values, and attitudes into behaviors. In this study, we will employ the cultural dimensions of individualism and power distance to determine whether there is truly a difference in the value of cooperation across cultures. Culture is self-construal, "a constellation of thoughts, feelings, and actions concerning the relation of the self to others and the self as distinct from others" (Singelis, Bond, Sharkey, \& Yiu Lai, 1999:316). The self is defined as indepen- 
dent in societies where individualism is the dominant societal cultural value; the self is defined as interdependent where its opposite, collectivism, is the dominant societal cultural value (Markus \& Kitayama, 1991). As a result, those in individualistic societies define personal goals as more important than group goals; the opposite is true in collectivistic societies (Schwartz, 1990, 1992, 1994; Triandis, 1988, 1990). Non-Western societies tend to be more collectivistic in behavior (Hofstede, 2001) - and 70 percent of the population lives in non-Western societies (Triandis, 1995)! Scholars have examined many different cultural dimensions, but the most prominent has been individualism (cf., Singelis, Triandis, Bhawuk, \& Gelfand, 1995).

Power distance, as a cultural dimension is the acceptance and expectation of inequalities which are basically hierarchical or resource differences (Hofstede, 2001). Individuals in higher power distance cultures often do not question statements of those in power (Yang, Mossholder, \& Peng, 2007). Organizations in higher power distance cultures often reflect this by having strict hierarchies and communication channels, with little visible input into decision making by lower ranking members. Organizations in higher power distance cultures are more likely to use hierarchy as a guide, rather than a rule. In these cultures, structures are often flat, and participative decision making has become a desirable trait (Hofstede, 2001). Singelis et al. (1995) and Triandis and Gelfand (1998) stated that power distance may covary with individualism/collectivism in many studies, making it difficult to distinguish between the two.

In the work of Singelis et al. (1995), a promising measurement instrument was promoted to measure horizontal and vertical individualism and collectivism. The research indicated that there is a tight matrix structure among the students surveyed in the pilot study. However, no other studies showing international reliability were found.

The two dimensions of individualism and power distance were chosen because of the frequency of their use and their salience in most of the business literature. In exploring these two dimensions, we do not mean to indicate that the other dimensions would not be of value, but instead that these two appear to be of particular value in the business communities that are interested in topics such as cooperation.

\subsection{Cooperation and cultural dimensions}

Cooperation emphasizes group accomplishments, so it is generally considered to be a collectivistic trait (Chatman, Polzer, Barsade, \& Neale, 1998). Variations in individualism are suspected to influence cooperation (Wagner, 1995), and this study seeks to determine whether power distance does as well. We have been unable to uncover prior research on this point. Many researchers speculate that, since cooperation diminishes personal resources that could be used to achieve personal goals, those in individualistic cultures would be more likely to avoid cooperation (Spence, 1985; Wagner, 1995). Earley (1989, 1993), Gabrenya, Latane, and Wang (1983), Hsu (1970), and Yang (1981) found collectivist group cooperation, although they did not measure the underlying structure. Wagner and Moch (1986) found that individualists may ignore groups if the goals conflict with personal desires, while collectivists may ignore their own personal desires to achieve group goals.

Similarity of values often fosters cooperation, as does similarities of status and social ties (Triandis, 2000). These similarities are strong in collectivistic ingroups and often lead to higher levels of cooperation than those found in individualistic ingroups (Hofstede, 2001; Triandis, 2000). Collectivists, by definition, have fewer and tighter ingroups than do individualists (Hofstede, 2001; Triandis, 2000). Helping others is a requirement of membership in collectivistic culture ingroups, creating focus and identity for the group (Moorman \& Blakely, 1995; Paine \& Organ, 2000). Therefore, this study is built on the supposition that those in collectivistic cultures would value cooperation more than would those in individualistic cultures.

Power distance would also seem to be a potential factor in cooperation and its value within different cultures. Because of the acceptance of inequalities in higher power distance cultures, group members would be expected to cooperate with those in power over them; however, those in lower power distance cultures might not feel the same pressures to comply.

\subsection{Purpose and hypotheses of the study}

The purpose of the study was twofold. The first is to determine whether cooperation can be operationalized through proxies in the same manner in cultures with various cultural dimension ratings (Hofstede, 2001). The work within this study is, therefore, to determine the cultural equivalence of the measure across cultures, using statistical validation methods.

The direct outcome of this proxy would indicate whether there is truly a difference in the value of cooperation across cultures with various ratings of individualism and power distance. Two hypotheses are posited from the review of the current literature:

(1) Cooperation will be more valued in collectivistic cultures than in individualistic cultures.

(2) Cooperation will be more valued in high power distance cultures than in individualistic cultures.

\section{Method}

\subsection{Sample and procedure}

A total of 6452 respondents working in various organizations in sixteen different countries participated in the study. The respondents were each born and held citizenship in their respective countries, listed alphabetically in Table 1 , along with the demographic data for the overall set and each country. The respondents were each employed in various industries, rather 
Table 1

Demographic and other data for sample.

\begin{tabular}{|c|c|c|c|c|c|c|c|}
\hline & Countries & $\begin{array}{l}\text { Individualism } \\
\text { Index/Power } \\
\text { Distance Index }^{\mathrm{a}}\end{array}$ & $\begin{array}{l}\text { Number of } \\
\text { respondents }\end{array}$ & Age & $\operatorname{Sex}^{\mathrm{b}}$ & Occupation $^{c}$ & Cronbach's $\alpha^{\mathrm{d}}$ \\
\hline 1 & Australia & $90 / 36$ & 744 & 37 & $\begin{array}{l}42.9 \mathrm{M} \\
56.7 \mathrm{~F}\end{array}$ & $\begin{array}{l}\text { Retail } 42.0 \\
\text { Health } 33.1\end{array}$ & .760 \\
\hline 2 & Canada & $80 / 39$ & 122 & 43 & $\begin{array}{l}14.2 \mathrm{M} \\
85.8 \mathrm{~F}\end{array}$ & Health 100 & .694 \\
\hline 3 & Chile & $23 / 63$ & 588 & 40 & $\begin{array}{l}44.5 \mathrm{M} \\
54.5 \mathrm{~F}\end{array}$ & $\begin{array}{l}\text { Finan } 39.9 \\
\text { Health } 35.4 \\
\text { Govt. } 24.7\end{array}$ & .686 \\
\hline 4 & France & $71 / 68$ & 93 & 37 & $\begin{array}{l}43.0 \mathrm{M} \\
57.0 \mathrm{~F}\end{array}$ & $\begin{array}{l}\text { Manuf } 40.9 \\
\text { Educ } 16.1 \\
\text { Finan } 11.8\end{array}$ & .641 \\
\hline 5 & Germany & $67 / 35$ & 256 & 38 & $\begin{array}{l}51.2 \mathrm{M} \\
48.8 \mathrm{~F}\end{array}$ & $\begin{array}{l}\text { Manuf } 25.4 \\
\text { Health } 17.2 \\
\text { Retail } 10.5 \\
\text { Finan } 10.2\end{array}$ & .717 \\
\hline 6 & India & $48 / 77$ & 458 & 36 & $\begin{array}{l}26.0 \mathrm{M} \\
28.6 \mathrm{~F}\end{array}$ & $\begin{array}{l}\text { Health } 54.6 \\
\text { Finan } 45.4\end{array}$ & .672 \\
\hline 7 & Lithuania & $50 / 45^{e}$ & 199 & 41 & $\begin{array}{l}15.1 \mathrm{M} \\
79.9 \mathrm{~F}\end{array}$ & Health 100 & .754 \\
\hline 8 & Malaysia & $26 / 104$ & 111 & - & $\begin{array}{l}64.9 \mathrm{M} \\
35.1 \mathrm{~F}\end{array}$ & Manuf 100 & .827 \\
\hline 9 & Poland & $60 / 68$ & 248 & 41 & $\begin{array}{l}57.7 \mathrm{M} \\
42.3 \mathrm{~F}\end{array}$ & $\begin{array}{l}\text { Manuf } 46.4 \\
\text { Retail } 25.4 \\
\text { Govt } 10.5\end{array}$ & .606 \\
\hline 10 & PRC & $20 / 80$ & 240 & 36 & $\begin{array}{l}68.6 \mathrm{M} \\
31.4 \mathrm{~F}\end{array}$ & Manuf 96.8 & .692 \\
\hline 11 & S. Korea & $18 / 60$ & 271 & 32 & $\begin{array}{l}26.9 \mathrm{M} \\
72.7 \mathrm{~F}\end{array}$ & Health 100 & .773 \\
\hline 12 & Taiwan & $17 / 58$ & 220 & 34 & $\begin{array}{l}10.9 \mathrm{M} \\
87.7 \mathrm{~F}\end{array}$ & Health 100 & .773 \\
\hline 13 & Turkey & $37 / 66$ & 1567 & 32 & $\begin{array}{l}32.5 \mathrm{M} \\
67.1 \mathrm{~F}\end{array}$ & Health 100 & .721 \\
\hline 14 & $\begin{array}{l}\text { United Arab } \\
\text { Emirates }\end{array}$ & $38^{f} / 80^{g}$ & 237 & 33 & $\begin{array}{l}61.4 \mathrm{M} \\
36.9 \mathrm{~F}\end{array}$ & $\begin{array}{l}\text { IT } 25.8 \\
\text { Health } 21.6 \\
\text { Finan } 16.1 \\
\text { Manuf } 16.1 \\
\text { Support } 10.2\end{array}$ & .803 \\
\hline 15 & United States & $91 / 40$ & 589 & 32 & $\begin{array}{l}39.4 \mathrm{M} \\
59.6 \mathrm{~F}\end{array}$ & $\begin{array}{l}\text { Health } 43.6 \\
\text { Manuf } 18.4\end{array}$ & .740 \\
\hline 16 & Venezuela & $12 / 81$ & 509 & 37 & $\begin{array}{l}64.4 \mathrm{M} \\
35.8 \mathrm{~F}\end{array}$ & $\begin{array}{l}\text { Manuf } 60.9 \\
\text { Health } 38.7\end{array}$ & .740 \\
\hline Total & & $\begin{array}{l}\text { World averages }^{\mathrm{a}} \\
\text { Individualism-43 } \\
\text { power distance-55 }\end{array}$ & 6452 & 35 & $\begin{array}{l}42 \mathrm{M} \\
58 \mathrm{~F}\end{array}$ & $\begin{array}{l}\text { Occupation }{ }^{\mathrm{c}} \text { health } \\
56.2 \\
\text { Manuf } 18.8\end{array}$ & .777 \\
\hline
\end{tabular}

a From Hofstede (2001) and http://www.geert-hofstede.com/hofstede_dimensions.php).

b Percentage of respondents.

c Percentage of major occupations listed ( $\geq 10 \%$ ).

d Cronbach's alpha (scale reliabilities) for each country for the scale comprising the Cooperation Index. Note: None showed significantly improved reliability if one or more questions are deleted.

e "Arab World" =Egypt, Iraq, Kuwait, Lebanon, Libya, and Saudi Arabia (http://www.geert-hofstede.com/hofstede_dimensions.php).

$\mathrm{f}$ Total number responding to the survey instrument.

g Mockaitis (2002, 2005).

than a student population. As suggested in Bhagat and McQuaid (1982) and Bhagat and Moustafa (2002), the instrument was translated in countries where the business language was not English, at the direction of country collaborator, with checks through back-translation for fidelity to the original instrument.

\subsection{Measures}

\subsubsection{Measure of country culture}

This study is built on Hofstede's $(1981,2001)$ analyses of country culture for the individualism and power distance dimensions, whose link between country and culture has been accepted in the mainstream cross-cultural organizational behavior literature, as discussed previously. 
Table 2

Factor analysis from each country.

\begin{tabular}{|c|c|c|c|c|c|c|}
\hline \multirow[t]{2}{*}{ Country } & \multirow{2}{*}{$\begin{array}{l}\text { Percent of variance } \\
\text { explained by } 1 \text { st factor }\end{array}$} & \multicolumn{5}{|c|}{ Eigenvalues for factor $1^{\mathrm{a}}$} \\
\hline & & Q1 & Q2 & Q3 & Q4 & Q5 \\
\hline Total data set & 52.981 & .722 & .727 & .749 & .745 & .695 \\
\hline Australia & 51.294 & .744 & .669 & .706 & .767 & .691 \\
\hline Canada & 53.121 & .726 & .772 & .832 & .778 & .486 \\
\hline Chile & 45.032 & .629 & .653 & .711 & .719 & .637 \\
\hline France & 42.821 & .771 & .596 & .723 & .726 & \\
\hline Germany & 48.608 & .791 & .614 & .679 & .789 & .586 \\
\hline India & 43.486 & .650 & .620 & .673 & .695 & .657 \\
\hline Lithuania & 50.647 & .742 & .747 & .737 & .668 & .659 \\
\hline Malaysia & 59.216 & .732 & .780 & .812 & .782 & .739 \\
\hline Poland & 39.200 & .590 & .566 & .697 & .652 & .617 \\
\hline People's Republic of China & 44.890 & .688 & .613 & .663 & .713 & .668 \\
\hline S. Korea & 52.608 & .746 & .675 & .759 & .744 & .699 \\
\hline Taiwan & 52.818 & .629 & .795 & .711 & .782 & .703 \\
\hline Turkey & 47.349 & .640 & .710 & .701 & .701 & .687 \\
\hline United Arab Emirates & 65.830 & .834 & .748 & .836 & .818 & .817 \\
\hline United States & 56.113 & .775 & .722 & .791 & .726 & .728 \\
\hline Venezuela & 49.272 & .720 & .724 & .702 & .693 & .669 \\
\hline
\end{tabular}

a Extraction using principal component analysis.

\subsubsection{Measure of cooperation}

The measure of cooperation consists of five statements providing a measure of individual attitudes toward cooperation, measured using a Likert scale (1: strongly disagree to 7: strongly agree). There was a cohesive scale with excellent face validity for use in measurement. These statements are:

(1) The well-being of my coworkers is important to me;

(2) If a coworker gets a prize, I would feel proud;

(3) I feel good when I cooperate with others;

(4) It is important to me that I respect decisions made by my groups; and

(5) I respect the majority's wishes in groups of which I am a member.

The survey is adapted on the work of Singelis et al. (1995), Triandis and Gelfand (1998), and Triandis (2002). We analyzed the entire survey used by Singelis et al. (1995), but there was no identifiable matrix structure and poor reliabilities in the international sample, except for the five questions noted above. We found this to be of interest, and pursued the cooperation perspective, as it is a critical ingredient of business effectiveness in cross-cultural management.

\subsection{Data analysis}

Data were analyzed with SPSS 17.0. Initially, factor analysis was undertaken to determine if there was indeed a single factor structure. To determine whether there was cross-cultural equivalence of the scale, Levine's test of homogeneity of variances was performed. One-way ANOVA with Welch test were used to assess differences in scores between the country/cultural groups on the variable.

\section{Results}

\subsection{Cross-cultural equivalency}

Before assuming that scales developed in one country are suitable for another, cross-cultural equivalency is determined. This has been a significant difficulty in cross-cultural empirical studies. Using Vandenberg and Lance's (2000) suggestions, Levine's test of homogeneity of variances was performed, since there was a single dependent variable. Results indicated no significant differences among the variances of the scale across cultures $(p=.000)$. This was taken as an excellent indication of the cross-cultural equivalency of the scale.

\subsection{Cohesion of the scale}

In examining cross-cultural responses to the scale, factor analysis was used. Principle component analysis without rotation showed a single factor matrix structure for the entire data set, as shown in Table 2. Results showed that one factor explains 52.981 percent of the variance and, when eigenvalues below .4 are suppressed, one factor emerges. The reliability of the scale was also tested, using the entire data set, and Cronbach's alpha was .777 for the five items, with no improvement if items were removed. 
Table 3

Cooperation scores.

\begin{tabular}{|c|c|c|c|}
\hline Country & $\begin{array}{l}\text { Cooperation } \\
\text { index }{ }^{a}\end{array}$ & $\begin{array}{l}\text { Percentage } \\
\text { respondents }^{\mathrm{b}}\end{array}$ & $\begin{array}{l}\text { Standard } \\
\text { deviation }\end{array}$ \\
\hline Australia & 5.51 & 99.6 & .875 \\
\hline Canada & 5.56 & 100 & .862 \\
\hline Chile & 6.28 & 99.3 & .686 \\
\hline France & 5.05 & 98.9 & .942 \\
\hline Germany & 5.17 & 100 & .863 \\
\hline India & 5.91 & 100 & .716 \\
\hline Lithuania & 5.24 & 100 & .944 \\
\hline Malaysia & 5.35 & 100 & .762 \\
\hline Poland & 5.63 & 100 & .753 \\
\hline People's Republic of China & 5.14 & 100 & .789 \\
\hline S. Korea & 5.14 & 100 & .774 \\
\hline Taiwan & 5.60 & 100 & .807 \\
\hline Turkey & 5.95 & 99.6 & .917 \\
\hline United Arab Emirates & 5.60 & 99.6 & 1.125 \\
\hline United States & 5.50 & 100 & .923 \\
\hline Venezuela & 6.22 & 100 & .828 \\
\hline Total & 5.80 & 99.6 & .885 \\
\hline
\end{tabular}

a Cooperation index = summated mean score for country (taking all respondents answering 4 or more of the five questions, i.e., 70 percent).

b Percentage of total country respondents answering 4 of 5 cooperation items.

\subsection{Country data}

There was no significant different attributable to age, gender, or industry group. ANOVA for the entire data set (Between Groups: Sum of Squares $=792.385 ; \mathrm{df}=15 ; F=79.908 ; p=.000$ ) demonstrates that there is no significant statistical variation between country respondent means. Welch test $(p=.00)$ indicates that there are no statistically different responses between the country respondent means.

Factor analysis was performed for each country group of responses. As shown in Table 2, we found a good factor matrix structure for each country, reflected in the factor structure for the entire dataset. Most of the countries had one major component, when eigenvalues less than .4 were suppressed. We also examined the reliability of the scale for each country, and Cronbach's alphas are given in Table 1. For each country, the alpha values is above the $\alpha=.6$ suggested for reliability in many cross-cultural papers, with most near or above the $\alpha=.7$ recommended for studies within the same culture (Nunnally, 1978; Vandenberg \& Lance, 2000).

Creating a mean Cooperation Index for each of the 6452 respondents was performed using a reductive method: Respondents must answer at least four of the five items ( 70 percent) before their responses can be used in the remaining analyses. Of the total respondents, 6423 (99.6 percent) answered four of the five items. An individual mean score of 1 indicated the lowest importance given to cooperation, while a score of 7 indicated the highest. With statistical validity and reliability, face validity, and content validity of the entire data set established, further analysis by country was undertaken.

The distributions of country means overlap, ranging from a mean of 5.05 (France) with a standard deviation of .942, to a mean of 6.28 (Chile) with a standard deviation of .686 on the 7 point scale. As shown in Table 3 and Fig. 1, the lowest average country mean is above the midpoint of the scale (4). This indicates that the majority of the respondents surveyed in each country believed that cooperation was important. Analyzing the small differences between countries is counterproductive and could lead to an oversimplification.

Table 1 shows the Individualism Index and Power Distance Index of different countries, based on Hofstede (2001) scores. We had thought to divide the countries, based on their Individualism Index and Power Distance Index, into high, low, and medium individualistic and power distance groups and analyze the data based on these divisions. At this point, correlation analysis was performed using the Individualism and Power Distance Indexes and the newly developed Cooperation Index of this study $(-0.182, p=.000 ; .157, p=.000$, respectively). In neither case was there a strong or significant correlation between cooperation and cultural dimension of the study (Fig. 2).

\section{Discussion and conclusions}

The multicultural data set of 6452 respondents indicated that there is an interrelationship of five questions that involve the concept of cooperation. Our first hypothesis proposed an inverse relationship, i.e., the lower the Individualism Index, the higher the mean on the Cooperation Index. Our second proposed a direct relationship, i.e., the higher the Power Distance Index, the higher the mean on the Cooperation Index. Our data shows that an individual's attitude toward cooperation is not a function of either index. Whether a person lives in an individualistic or collectivistic country or whether the power distance is high or low, the understanding and agreement as to the importance of cooperation was similar. It would seem that cooperation is not a function of these particular cultural dimensions. The correlation of cooperation and power distance 


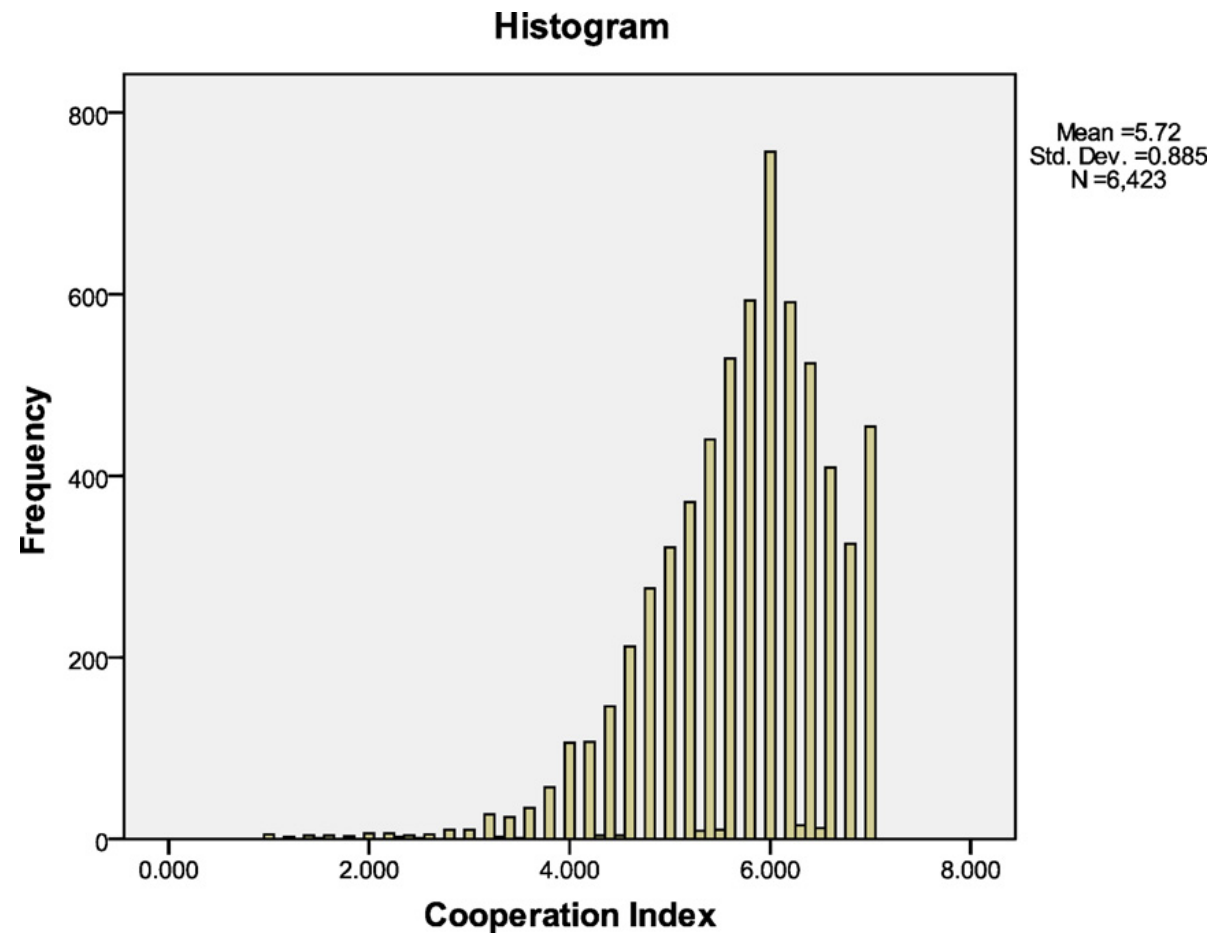

Fig. 1. Frequency of totaled responses to cooperation questions.

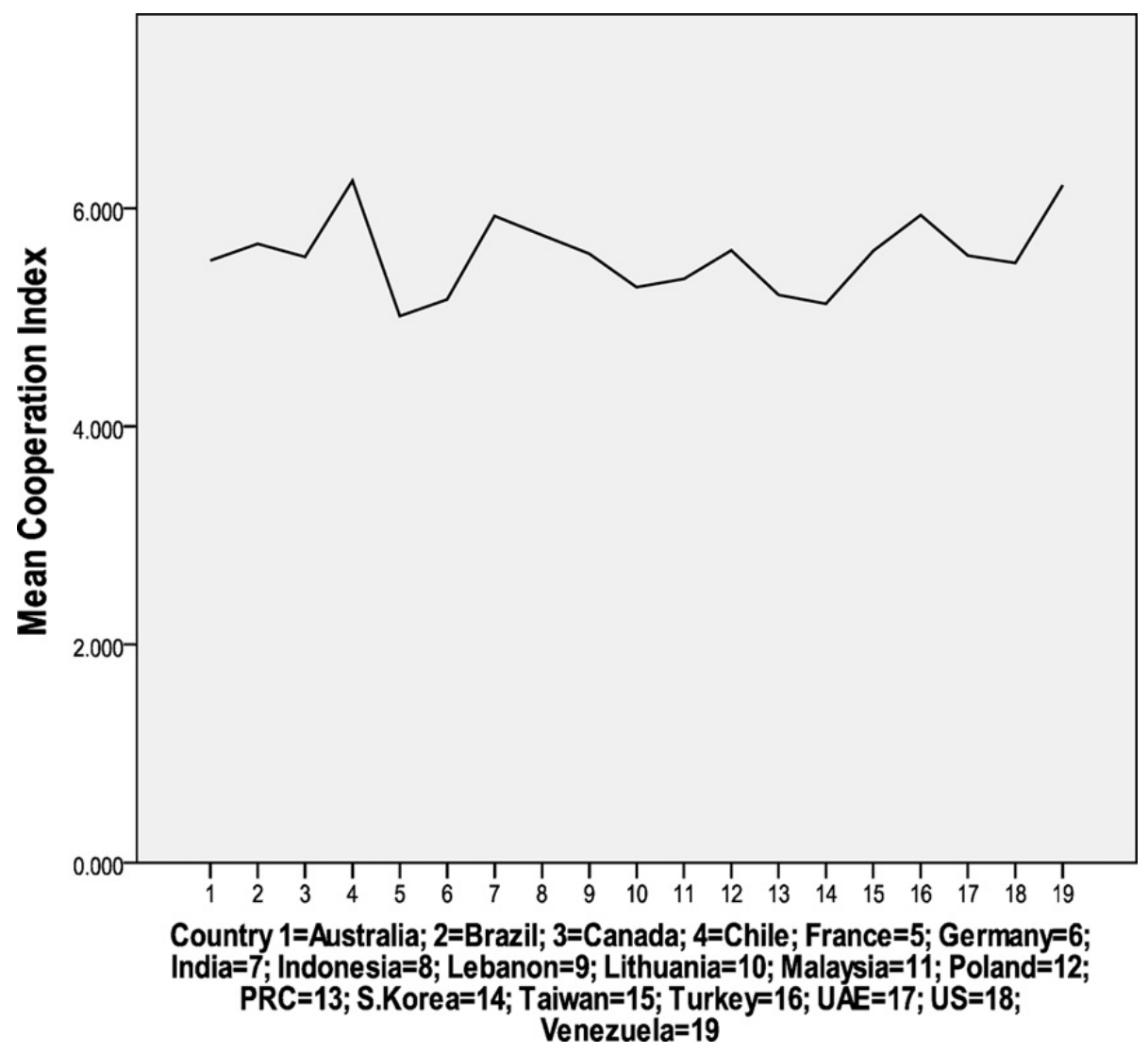

Fig. 2. Cooperation index means for countries. 
Table 4

Pearson's correlation analysis.

\begin{tabular}{llll}
\hline & & $\begin{array}{l}\text { Cooperation } \\
\text { index }\end{array}$ & $\begin{array}{l}\text { Hofstede Individualism } \\
\text { Index }\end{array}$ \\
\hline Cooperation index & $\begin{array}{l}\text { Pearson's correlation } \\
\text { Pvalue }\end{array}$ & 1 \\
& $N$ & 6423 & \\
Dofstance Index & Pearson's correlation & $-.182^{* *}$ & .000 \\
& $P$ value & 6224 & 6253 \\
Hofstede Power Distance Index & $N$ & $.157^{* *}$ & $-.787^{* *}$ \\
& Pearson's correlation & .000 & .000 \\
& $P$ value & 6224 & 6253 \\
\hline
\end{tabular}

${ }^{* *}$ Correlation is significant at the 0.01 level (2-tailed).

is interesting, and we plan further studies to determine the nature of the correlation, which was not reflected in the way that individuals perceive cooperation (Table 4).

Our data shows no statistically significant differences in the means; therefore, we can see that cooperation at work is strongly valued among all cultures. Therefore, we can strongly suggest that, even if two groups of people have different languages and cultures, the can cooperate using a similar basis of understanding of what cooperation entails. We were somewhat surprised to find that little empirical work had been done using cooperative behaviors across cultures. In analyzing the multinational data, we hope to have an impact on the theoretical view of cross-cultural cooperation.

As globalization increases exponentially with unforeseen technological and economic changes, it is crucial to understand those who function in different societies. We often make false assumptions about the "West," assuming that individuals in these countries are similar and that each person has an individualistic outlook (Hofstede, 2001). We understand the dynamic between the knowledge developed in the West and considered "universal" (Prasad, 1997) and "native knowledge" from elsewhere (Banerjee, 2000; Banerjee \& Linstead, 2001; Said, 1981; waThiong'o, 1981, 2006).

In looking at our data, cooperation appears the same, but there are some striking differences that might affect individuals differently. For example, one approach to human relations, called the investment approach (Tsui, Pearce, Porter, $\&$ Tripli, 1997) indicates that more contextual performance, including cooperation, occurs when employees perceive that the employer is investing in them. Other research indicates that supervisors who are cooperative toward employees are likely to receive cooperation in return (Koster \& Sanders, 2006), and this is a likely affect among peers as well (Bommer, Miles, \& Grover, 2003).

Our primary factor, cooperation, is the subject of this paper, and we hope this provides new and useful information for the discussion and analysis of the concept. Given the differences between individualist and collectivist societies, it is likely that the reasons for cooperation might be different, which is an interesting idea, but beyond the scope of this paper. We suggest that there is much benefit in examining cross-cultural cooperation, because of its importance in the future, as we turn from individualized work structures in a single cultural environment to teamwork in a global context.

\section{Appendix A.}

Fran Brew, Macquarie University, Australia Betania Tanure, PUC-Minas, Brazil

Vilma Coutina-Hill, Carleton University, Canada

Ben Kuo, University of Windsor, Canada

Catherine T. Kwantes, University of Windsor, Canada

Jose Rojas-Mendez, Carleton University, Canada

Tae-Yeol Kim, China Europe International Business School, China

Annamaria Lammel, University Paris 8, France

Stefan Schmid, University of Applied Sciences, Koblenz, Germany

B.N. Srivastava, Indian Institute of Management Calcutta, India

Bernadette Setiadi, Universitas Indonesia, Indonesia

Tim Keeley, Kyushu Sangyo University, Japan

Gene Surkiene, Vilnius University, Lithuania

Aizzat Mohd. Nasurdin, Universiti Sains, Malaysia

Audra I. Mockaitis, Monash University, Australia

Mikal Nowak, University of Gdansk, Poland

Sang-Pyo Kim, Jinju National University, South Korea

Mansoo Shin, Korea University Business School, South Korea

Fu-Sheng Tsai, Cheng Shiu University, Taiwan

Ling Ling Wu, National Taiwan University, Taiwan

Asuman Akdogan, Erciyes University, Turkey

Ezel Esatoglu, Ankara University, Turkey

Murat Gumus, Canakkale Onsekiz Mart University, Turkey 


\section{Appendix A. (Continued)}

Mustafa Koyuncu, Nevsehir University, Turkey

M. Kemal Oktem, Hacettepe University, Turkey

Deniz Tasci, Anadolu University, Turkey

Nuray Tokgoz, Anadolu University, Turkey

Darwish Yousef, United Arab Emirates University, United Arab Emirates

Laura Salciuviene, Lancaster University, United Kingdom

Suzana B. Rodriguez, University of Birmingham, United Kingdom

Nadine JbeilyChamseddine, Atlanta, GA, United States

David Ford, University of Texas at Dallas, United States

Ujvala Rajadhyaksha, St. Mary's College, Notre Dame, United States

Olga Soler, University Central de Venezuela, Venezuela

\section{References}

Allred, B. B., Snow, C. C., \& Miles, R. E. (1996). Characteristics of managerial careers in the 21st century. Academy of Management Executive, 10(4), 17-27.

Anderson, C. M., \& Putterman, L. (2006). Do non-strategic sanctions obey the law of demand? The demand for punishment in the voluntary contribution mechanism. Games and Economic Behavior, 54, 1-24.

Avolio, B. J., \& Luthans, F. (2006). The high impact leader: Moment matter in accelerating authentic leadership development. New York: McGraw Hill.

Banerjee, S. B. (2000). Whose land is it anyway? National interest, indigenous stakeholders, and colonial discourses. Organization and Environment, 13, 3-38.

Banerjee, S. B., \& Linstead, S. (2001). Globalization, multiculturalism, and other fictions: Colonialism for the new millennium? Organization, 8, 683-722.

Barnard, C. I. (1938). The functions of the executive. Cambridge, MA: Harvard University Press.

Bhagat, R. S., Kedia, B., Harveston, P. D., \& Triandis, H. C. (2002). Cultural variations in the cross border transfer of organizational knowledge: An integrative framework. Academy of Management Review, 27(2), 204-221.

Bhagat, R. S., \& McQuaid, S. J. (1982). Role of subjective culture in organizations: A review and directions for future research. Journal of Applied Psychology Monograph, 67(5), 653-685

Bhagat, R. S., \& Moustafa, K. S. (2002). How non-Americans view American use of time: A cross-cultural perspective. In P. Boski, F. J. R. van de Vijver, \& A. M. Chodynicka (Eds.), New directions in cross-cultural psychology (pp. 183-191). Poland: Polish Psychological Association.

Blau, P. (1964). Exchange and power in social life. New York: Wiley.

Bommer, W. H., Miles, E. W., \& Grover, S. L.(2003). Does one good turn deserve another? Coworker influence on employee citizenship. Journal of Organizational Behavior, 24, 181-197.

Borman, W. C., \& Motowidlo, S. J. (1993). Expanding the criterion domain to include elements of contextual performance. In N. Schmitt, \& W. C. Borman (Eds.), Personnel selection in organizations (pp. 71-98). San Francisco: Jossey-Bass.

Carpenter, J. (2007). The demand for punishment. Journal of Economic Behavior in Organizations, 62, 522-542.

Chatman, J. A., Polzer, J. T., Barsade, S. G., \& Neale, M. A. (1998). Being different yet feeling similar: The influence of demographic composition and organizational culture on work processes and outcomes. Administrative Science Quarterly, 43, 749-780.

Contractor, F. J., \& Lorange, P. (2002). The growth of alliances in the knowledge based economy. International Business Review, 11(4), 485-502.

Deutsch, M. (1949). A theory of cooperation and competition. Human Relations, 2, 129-152.

Durkheim, E. (1938). The Rules of Sociological Method. Chicago: University of Chicago Press.

Earley, P. C. (1989). Social loafing and collectivism: A comparison of the United States and the People's Republic of China. Administrative Science Quarterly, 34, 565-581.

Earley, P. C. (1993). East meets West meets Mideast: Further explorations of collectivistic and individualistic work groups. Academy of Management Journal, $36,319-348$

Ericsson, K. A., \& Charness, N. (1994). Expert performance: Its structure and acquisition. American Psychologist, 49, $725-747$.

Fehr, E., \& Gintis, H. (2007). Human motivation and social cooperation: Experimental and analytical foundations. Annual Review of Sociology, 33, 43-64.

Gabrenya, W. K., Jr., Latane, B., \& Wang, Y. E. (1983). Social loafing in cross-cultural perspective. Journal of Cross-Cultural Psychology, $14,368-384$.

Gouldner, A. W. (1960). The norm of reciprocity: A preliminary statement. American Sociological Review, 25, 161-178.

Hage, J. (1980). Theories of Organizations: Form, Process, and Transformation. New York: Wiley.

Hirschman, A. O. (1970). Exit, voice, and loyalty: Responses to decline in firms, organizations and states. Cambridge, MA: Harvard University Press.

Hofstede, G. (1981). Culture and organizations. London: McGraw-Hill.

Hofstede, G. (2001). Culture's consequences: comparing values, behaviors, institutions, and organizations across nations. Thousand Oaks, CA: Sage.

Holm, D. B., Eriksson, K., \& Johnson, J. (1996). Business networks and cooperation in international business relationships. Journal of International Business Studies, 27(5), 1033-1053.

Homans, G. C. (1974). Social Behavior: Its Elementary Forms. New York: Harcourt Brace Jovanovich.

Hsu, F. L. (1970). Americans and Chinese: Purpose and fulfillment in great civilizations. Garden City: Natural History Press.

Kerr, S. (1975). On the folly of rewarding A, while hoping for B. Academy of Management Journal, 18, 769-783.

Kluckhohn, C. (1954). Culture and behavior. In G. Linzey (Ed.), Handbook of social psychology (pp. 921-976). Cambridge, MA: Addison-Wesley.

Koster, F., \& Sanders, K. (2006). Organisational citizens or reciprocal relationships? An empirical comparison. Personnel Review, 35(5), 519-537.

LePine, J. A., \& Van Dyne, L. (2001). Voice and cooperative behavior as contrasting forms of contextual performance: Evidence of differential relationships with big five personality characteristics and cognitive ability. Journal of Applied Psychology, 80(2), 326-336.

Markus, H., \& Kitayama, S. (1991). Culture and the self: Implications for cognition, emotions, and motivation. Psychological Review, 98, 224-253.

Mockaitis, A. I. (2002). The national culture dimensions of Lithuania. Ekonomika, 59(1), 67-77.

Mockaitis, A. I. (2005). A cross cultural study of leadership attitudes in three Baltic Sea Region countries. International Journal of Leadership Studies, 1(1), 44-63.

Moorman, R. H., \& Blakely, G. L. (1995). Individualism-collectivism as an individual difference predictor of organizational citizenship behavior. Journal of Organizational Behavior, 16, 127-142.

Motowidlo, S. J., \& Schmit, M. J. (1999). Performance assessment in unique jobs. In D. R. Ilgen, \& E. D. Pulakos (Eds.), The changing nature of performance: Implications for staffing, motivation, and development (pp. 56-86). San Francisco: Jossey-Bass.

Mowday, M. T., Steers, L. W., \& Porter, R. M. (1982). Employee-organization linkages: The psychology of commitment, absenteeism and turnover. New York: Academic Press.

Nunnally, J. C. (1978). Psychometric theory (2nd ed.). New York: McGraw-Hill.

Organ, D. W. (1997). Organizational Citizenship Behavior: It's Construct Clean-Up Time. Human Performance, 10(2), 85-97.

Ostrom, E., Walker, J., \& Gardner, R. (1992). Covenants with and without a sword-Self-governance is possible. American Political Science Review, 404-417.

Paine, J. B., \& Organ, D. W. (2000). The cultural matrix of organizational citizenship behavior: Some preliminary conceptual and empirical observations. Personnel Psychology, 48, 45-59. 
Park, S. H., \& Russo, M. V. (1996). When competition eclipses cooperation: An event history analysis of joint venture failure. Management Science, 42(6), $875-890$.

Prasad, A. (1997). Provencializing Europe: Towards a postcolonial reconciliation: A critique of Baconian science as the last stand of imperialism. Studies in Culture, Organisations, and Societies, 3, 91-117.

Roberts, L. M. (2006). Shifting the lens on organizational life: The added value of positive scholarship. Academy of Management Review, $31,292-305$.

Said, E. (1981). Covering Islam: How the media and the experts determine how we see the rest of the world. New York: Pantheon.

Sattler, H., Schrader, S., \& Luthje, C. (2003). Informal cooperation in the US and Germany: Cooperative managerial capitalism versus competitive managerial capitalism in interfirm information trading. International Business Review, 12(3), 273-296.

Schwartz, S. H. (1990). Individualism-collectivism. Critique and proposed refinements. Journal of Cross-Cultural Psychology, 21, $139-157$.

Schwartz, S. H. (1992). Universals in the context and structure of values: Theoretical advances and empirical tests in 20 countries. In M. Zanna (Ed.), Advances in experimental social psychology (pp. 1-66). New York: Academic Press.

Schwartz, S. H. (1994). Beyond individualism and collectivism: New cultural dimensions of values. In U. Kim, H. C. Triandis, C. Kagitcibasi, S.-C. Choi, \& G. Yoon (Eds.), Individualism and collectivism: Theory, method, and applications (pp. 85-122). Newbury Park, CA: Sage.

Seligman, M. E. P., \& Csikszentmihalyi, M. (2000). Positive psychology. American Psychologist, 55, 5-14.

Shweder, R., \& LeVine, R. A. (1984). Culture theory: Essays on mind, self, and emotion. Cambridge, UK: Cambridge University Press.

Singelis, T. M., Bond, M., Sharkey, W. F., \& Yiu Lai, C. S. (1999). Unpackaging culture's influence on self-esteem and embarrassability: The role of self-construals. Journal of Cross-Cultural Psychology, 30, 315-341.

Singelis, T. M., Triandis, H. C., Bhawuk, D. P. S., \& Gelfand, M. J. (1995). Horizontal and vertical dimensions of individualism and collectivism: A theoretical and measurement refinement. Cross-Cultural Research, 29(3), 240-275.

Skinner, B. F. (1981). Selection by consequences. Science, 213, 501-504.

Smith, A. (1991). 1776/1991. The Wealth of Nations. Prometheus Books.

Sonnentag, S. (2000). Excellent performance: The role of communication and cooperation processes. Applied Psychology: An International Review, 49(3), 483-497.

Spence, J. T. (1985). Achievement American style: The rewards and costs of individualism. American Journal of Sociology, 82, 291-308.

Stevens, M. J., \& Campion, M. A. (1994). The knowledge, skills, and ability requirements for teamwork: Implications for human resource management. Journal of Management, 20, 503-530.

Sutcliffe, K. M., \& Vogus, T. (2003). Organizing for resilience. In K. S. Cameron, J. E. Dutton, \& R. E. Quinn (Eds.), Positive organizational scholarship (pp. 94-110). San Francisco: Berrett-Koehler.

Triandis, H. C. (1988). Collectivism versus individualism: A reconceptualization of a basic concept in cross cultural social psychology. In G. K. Verma, \& C. Bagley (Eds.), Cross-cultural studies of personality, attitudes, and cognition (pp. 60-95). London: Macmillan.

Triandis, H. C. (1990). Cross cultural studies of individualism and collectivism. In J. Berman (Ed.), Nebraska symposium on motivation, 1989 (pp. 41-133). Lincoln, NE: University of Nebraska Press.

Triandis, H. C. (1995). Individualism and collectivism. Boulder, CO: Westview Press.

Triandis, H. C. (1996). The psychological measurement of cultural syndromes. American Psychologist, 51(4), 407-415.

Triandis, H. C. (2000). Culture and conflict. International Journal of Psychology, 35(2), 145-152.

Triandis, H. C. (2002). Unpublished work on horizontal and vertical individualism and collectivism.

Triandis, H. C., \& Gelfand, M. J. (1998). Converging measurement of horizontal and vertical individualism and collectivism. Journal of Personality and Social Psychology, 74(1), 118-124.

Tsui, A. S., Pearce, J. L., Porter, L. W., \& Tripli, A. M. (1997). Alternative approaches to the employee-organization relationship: Does investment in employees pay off? Academy of Management Journal, 40, 1089-1121.

Vandenberg, R. J., \& Lance, C. E. (2000). A Review and Synthesis of the Measurement Invariance Literature: Suggestions, Practices, and Recommendations for Organizational Research. Organizational Research Methods, 3(1), 4-69.

Van Dyne, L. L., Cummings, L. L., \& Parks, J. M. (1995). Extra-role behaviors: In pursuit of construct and definitional clarity (A bridge over muddied waters). In B. M. Staw, \& L. L. Cummings (Eds.), Research in organizational behavior (pp. 215-285). Greenwich, CT: JAI Press.

Van Scotter, J. R., Motowidlo, S. J., \& Cross, T. C. (2000). Effects of task performance and contextual performance on systemic rewards. Journal of Applied Psychology, 85(4), 526-535.

Wagner, J. A., III, \& Moch, M. K. (1986). Individualism-Collectivism: Concept and Measure. Group Er Organization Studies, 11(3), $280-304$.

waThiong'o, N. (1981). Writers in politics: Essays. Exeter, NH: Heinemann.

waThiong'o, N. (2006). In R. Sander, \& B. Lindfors (Eds.), NguguwaThiong'o speaks: Interviews with the Kenyan Writer. Trenton, NJ: Africa World Press.

Wagner, J. A., III. (1995). Studies of individualism-collectivism: Effects on cooperation in small groups. Academy of Management Journal, 38(1), $152-172$.

West, M. A., Borrill, C. S., \& Unsworth, K. L. (1998). Team effectiveness in organizations. In C. L. Cooper, \& I. T. Robertson (Eds.), International Review of Industrial and Organizational Psychology (pp. 1-48). Chichester, UK: Wiley.

Wilkinson, I., \& Young, L. (2001). On cooperating: Firms, relations, and networks. International Business Review, 55(2), 123-132.

Yamagishi, T. (1986). The provision of a sanctioning system as a public good. Journal of Personality and Social Psychology, 51, $110-116$.

Yang, J., Mossholder, K. W., \& Peng, T. K. (2007). Procedural justice climate and group power distance: An examination of cross-level interaction effects. Journal of Applied Psychology, 92(3), 681-692.

Yang, K. S. (1981). Social orientation and individual modernity among Chinese students in Taiwan. Journal of Social Psychology, 113, 159-170. 